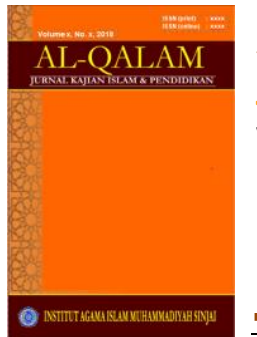

AL-QALAM

Jurnal Kajian Islam \& Pendidikan

Volume 06 No 022014

ISSN (print) : :1858-4152

ISSN (online) : -

Homepage : http://journal.iaimsinjai.ac.id/index.php/al-qalam

\title{
LINGKUNGAN PEMBELAJARAN YANG EFEKTIF
}

\author{
Oleh : Sardiyanah ${ }^{1}$ \\ $* * *$
}

\begin{abstract}
Abstrak
Lingkungan Pembelajaran yang Efektif. Salah satu aspek penting keberhasilan dalam proses pembelajaran yang dilakukan oleh guru menurut Muhammad Saroni adalah penciptaan kondisi pembelajaran yang efektif. Lingkungan belajar adalah segala sesuatu yang berhubungan dengan tempat proses pembelajaran dilaksanakan. Lingkungan ini mencangkup dua hal utama, yaitu lingkungan fisik dan lingkungan sosial. Untuk menciptakan lingkungan belajar yang efektif diperlukan strategi manajemen kelas, dan strategi positif untuk membuat anak mau bekerja sama. Agar proses pembelajaran dapat berjalan lancar, maka kelas perlu punya aturan dan prosedur yang jelas. karakteristik lingkungan pembelajaran yang efektif adalah seтиa apa yang diciptakan dalam kelas pembelajaran/ruang kelas "berbicara" artinya mempunyai perang masing-masing sehingga suasana pembelajaran menggairahkan dan mencapai tujuan pembelajaran. Lingkungan belajar menjadikan siswa dalam belajar terasa gembira, tidak ada tekanan, tidak ada usaha yang tidak dihargai, tercipta masyarakat belajar (learning Communiy), dan maju bersama tiap siswa untuk mewujudkan belajar yang berenergi.
\end{abstract}

Kata Kunci: lingkungan pembelajaran, belajar, efektif.

\section{PENDAHULUAN}

A. Latar Belakang

$\mathrm{H}$ asil pembelajaran banyak dipengaruhi oleh proses pembelajaran siswa, perencanaan pembelajaran, dan penataan lingkungan baik belajar maupun sosial dalam kelas, yang selanjutnya akan berdampak pada kualitas hasil belajar siswa. ${ }^{2}$ Fenomena yang terjadi, terdapat kecenderungan bahwa pelaksanaan pembelajaran kurang memperhatikan lingkungan belajar. Lingkungan belajar siswa di sekolah baik di kelas maupun di lingkungan kelas kurang ditata sedemikian rupa yang mendukung proses pembelajaran di kelas, dan para guru dalam mengajar menggunakan model atau pendekatan pembelajaran mengikuti yang sedang dikembangkan namun tidak dibarengi dengan setting kelas yang dituntut oleh model atau pendekatan yang digunakan tersebut. $^{3}$

${ }^{1}$ Dosen STAI Muhammadiyah Sinjai

${ }^{2}$ Conny Semiawan, dkk, Pendidikan Ketrampilan Proses, Bagaimana Mengaktifkan Siswa dalam Belajar.\{Jakarta:PT Gramedia, 1992\},h 55

${ }^{3}$ Seksi Kajian LPMP Kalbar,2006

Al-Qalam | Volume 6 Nomor 2, 2014 


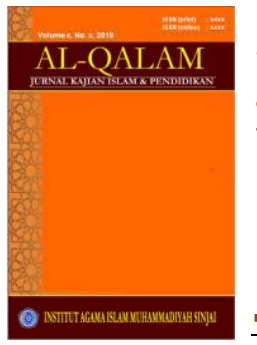

AL-QALAM

Jurnal Kajian Islam \& Pendidikan

Volume 06 No 022014

ISSN (print) : :1858-4152

ISSN (online) : -

Homepage : http://journal.iaimsinjai.ac.id/index.php/al-qalam

Dalam teori belajar konstruktivisme individual (teori konstruktivisme Piaget),yang menekankan bahwa pengetahuan kita itu adalah konstruksi (bentukan) kita sendiri dan teori belajar konstruktivisme sosial (teori konstruktivisme Vygotsky), yang menekankan perlunya interaksi sosial, juga menurut Von Glasersferld,mengatakan bahwa pengetahuan itu dibentuk oleh struktur konsepsi seseorang sewaktu dia berinsteraksi dengan lingkungannya. ${ }^{4}$

Penerapan proses pembelajaran yang memberikan keluasan kepada siswa untuk aktif membangun kebermaknaan sesuai dengan pemahaman yang telah mereka miliki memerlukan serangkai kesadaran akan makna bahwa pengetahuan tidak bersifat objektif dan stabil, tetapi bersifat temporer dan tidak menentu, tergantung dari persepsi subyektif individu dan individu yang berpengetahuan menginterprestasikan serta mengkonstruksi suatu realita berdasarkan pengalaman dan interaksinya dengan lingkungan. Pembelajaran konstruktifis sebagai salah satu pendekatan dalam menciptakan proses pembelajaran yang memberikan keleluasaan kepada siswa untuk aktif membangun kebermaknaan sesuai dengan pemahaman yang mereka miliki.

Selain itu juga untuk mengembangkan wawasan tentang ragam sistem pembelajaran beserta subtansi pola yang ditawarkan. Sehingga akan menghasilkan hasil belajar yang efektif dan memberikan manfaat bagi peserta didik. Menurut Milan Rianto, tingkat keberhasilan pembelajaran amat ditentukan oleh kondisi yang terbangun selama pembelajaran. Kondisi pembelajaran yang semakin kondusif, maka tingkat keberhasilan peserta didik dalam belajarnya akan semakin tinggi dan sebaliknya. Atau terciptannya kondisi pembelajaran yang efektif akan menjadikan proses pembelajaran berlangsung secara efektif dan efesien dan peserta didik berhasil dalam mewujudkan tujuan /kompetensi yang diharapkan sebagai dampaknnya. ${ }^{5}$

\section{B. Rumusan masalah}

Berdasarkan latar belakang masalah yang ada di atas, maka rumusan masalah yang akan penulisan bahasa dalam tulisan ini adalah sebagai berikut;

1. Apa yang dimaksud dengan lingkungan belajar dan macam-macamnya?

2. Bagaimana cara menciptakan lingkungan belajar yang efektif?

3. Bagaimana hubungan antara lingkungan belajar dengan hasil pembelajaran?

4. Bagaimana cara menata lingkungan belajar di kelas?

\section{PEMBAHASAN}

4 Kusmoro, Pengaruh Model PAKEM Denga Pendekatan Konstruktivisme dan Cooperative Learning Dalam Pembelajaran Sains Di Tinjau Dari Lingkungan Belajar Siswa. Tenis UNS: \{Tidak Ditertibkan : 2008\}, h.60.

${ }^{5}$ Milan Rianto, Pengelolaan Kelas Model Pakem. \{Jakarta :Dirjen PMPTK,2007\},H.1 


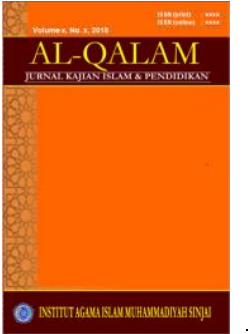

\section{A. Pengertian Lingkungan Belajar}

Salah satu aspek penting keberhasilan dalam proses pembelajaran yang dilakukan oleh guru menurut Muhammad Saroni adalah penciptaan kondisi pembelajaran yang efektif ${ }^{6}$. Kondisi pembelajan efektif adalah kondisi yang benar-benar kondusif, kondisi yang benar-benar sesuai dan mendukung kelancaran serta kelangsungan proses pembelajaran. Indra Djati sidi menegaskan "bahwa dalam pelaksanaan belajar mengajar, setiap guru harus dapat menciptakan suasana belajar yang menyenangkan, suasana belajar mengajar yang hidup, mengembangkan alat peraga yang sesuai, memanfaatkan sumber belajar yang sesuai,

Memotivasi siswa yang berpartisipasi dalam proses blajar mengajar dan lingkungan belajar dikelas yang kondusif." ${ }^{7}$ agar pembelajaran yang benar-benar kondusif maka guru mempunyai peranaan yang sangat penting dalam menciptakan kondisi pembelajaran tersebut. Di antara yang dapat diciptakan guru untuk kondisi tersebut adalah penciptaan lingkungan belajar.

Lingkungan belajar menurut Muhammad Saroni adalah segala sesuatu yang berhubungan dengan tempat proses pembelajaran dilaksanakan. Lingkungan ini mencangkup dua hal utama, yaitu lingkungan fisik dan lingkungan sosial, kedua aspek lingkungan tersebut dalam proses pembelajaran haruslah saling mendukung, sehingga siswa merasa kerasan tanpa ada tekanan ataupun keterpaksaan ${ }^{8}$.

Dari kutipan tersebut dikatakan bahwa lingkungan belajar merupakan situasi buatan yang menyangkut lingkungan fisik maupun yang menyangkut lingkungan sosial. Dengan demikian lingkungan belajar dapat diciptakan sedemikian rupa, sehingga mampu memfasilitasi siswa untuk melaksanakan kegiatan belajar, selanjutnya lingkungan belajar dapat dilihat dari interaksi belajar mengajar yang merupakan konteks terjadinya pengalaman belajar ,dan dapat berupa lingkugan fisik dan lingkugan non fisik.

Menurut Madi Aip Mariana, lingkungan belajar dapat mereflesikan ekspetasi yang tinggi untuk kesuksesan seluruh siswa lingkungan tersebut mengacu pada ruang secara fisik tempat belajar ,lingkungan sosial dan psikologi siswa yang mendorong belajar, perlakuan dan etika dalam menggunakan mahluk hidup, dan keamanan dalam area belajar yang berhubungan dengan pembelajaran sains ${ }^{9}$.

Berdasarkan uraian pendapat tentang lingkugan belajar tersebut di atas maka dapat disarikan bahwa lingkungan belajar yang dikelola adalah terutama bagaimana mengemas suasana kelas belajar, kelas belajarnya, dan sumber-sumber belajar yang ada di sekolah ataupun yang darat diadakan dari dibuat/alam lingkungan sekolah. Lingkungan belajar dalam hal terutama di kelas adalah

6 Paul Suparno,Filsafat Konstruktivisme Dalam Pendidikan \{Yogyakarta :Penerbit Kanisium 2005\}, h 81-82

${ }^{7}$ Ibid

${ }^{8}$ ConnySemiawan,dkk Op. Cit, h. 82-84

${ }^{9}$ IMade Alit Mariana, HO. Science For All,PPPG IPA \{Bandung, 2005\}, h 13 


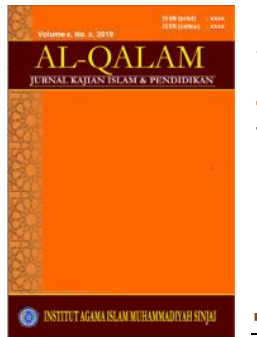

sesuatu yang diupayakan atau diciptakan oleh guru agar proses pembelajaran atau konteks pembelajaran yang semestinya. Lingkungan belajar dikelas sebagai situasi buatan yang berhubungan dengan pembelajaran atau konteks yang terjadinya pengalaman belajar, dapat diklasifikasikan yang menyangkut; 1) lingkungan (keadaan ) fisik, dan 2) lingkungan sosial ${ }^{10}$.

\section{Lingkungan fisik}

Lingkungan fisik memiliki beberapa arti, antara lain:

a. Lingkungan fisik adalah lingkungan yang memberi peluang gerak dan segala aspek yang berhubungan dengan upaya penyegaran pikiran bagi siswa setelah mengikuti proses pembelajaran yang sangat membosankan

b. Lingkunganh fisik ini meliputi saran prasarana pembelajaran yang dimiliki sekolah seperti lampu, ventilasi, bangku, tempat duduk yang sesuai dengan siswa, dan lain sebagainya. Lingkungan fisik yaitu lingkungan yang ada disekitar siswa baik itu di kelas, di sekolah, atau di luar sekolah yang perlu dioptimalkan pengelolaanya agar interaksi belajar mengajar lebih efektif dan efisien. Artinya lingkungan fisik dapat difungsikan sebagai sumber atau tempat belajar yang direncanakan atau dimanfaatkan.

c. Yang termasuk lingkungan belajar tersebut di antaranya adalah kelas laboratorium, tata ruang, situasi fisik yang ada di sekitar kelas, dan sebagainya."

Dari uraian diatas maka dapat disarikan bahwa lingkungan fisik adalah lingkungan yang ada di sekitar siswa belajar berupa sarana fisik baik yang ada di lingkungan sekolah maupun di lingkungan sekolah termasuk di masyarakat siswa yang berada. Dalam uraian ini lingkungan fisik lebih ditekankan dalam lingkungan fisik dalam ruang kelas belajar disekolah, alat/ media belajar yang ada, dan alat/ media belajar yang dapat dibuat sendiri diambil lingkungan.

\section{Lingkungan sosial}

Lingkungan sosial berhubungan dengan pola interaksi antar personil yang ada di lingkungan sekolah secara umum. Lingkungan sosial yang baik memungkinkan para siswa untuk berinteraksi secara baik, siswa dengan siswa, guru dengan siswa, guru dengan guru, atau dengan karyawan, dan siswa dengan karyawan, serta secara umum interaksi antara personil. Dan kondisi pembelajaran yang kondusif hanya dapat dicapai jika interaksi sosial ini berlangsung secara baik, lingkungan sosial yang kondusif dalam hal ini, misalnya adanya keakraban yang profesiuonal antar guru dan siswa dalam proses penbelajaran"

Oleh karena itu dalam lingkungan sosial kelas hendaknya juga diciptakan sekondusif mungkin,n agar suasana kelas dapat digunakan sebagai ajang dialaok mendalam dan berfikir kritis yang menjunjung tinggi prinsip-prinsip manusiawi

${ }^{10}$ Roestiyah dan Yumiati Suharto.. Strategis Belajar Mengajar \{Bandung:Bina Aksara. 1995 \},s h.95 


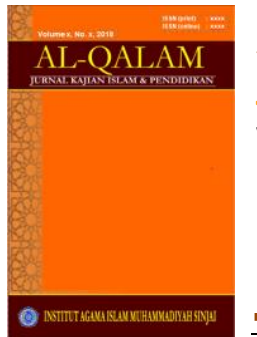

empati, dan lain-lain, demokratis serta religius. Selanjutnya lingkungan non fisik/ lingkungan sosial dapat dikembangakan fungsinya yaitiu untuk menciptakan suasana belajar yang nyama dan kondusif serta adanya musik yang digunakan sebagai latar pada saat interaksi belajar mengajar berlangsung. Musik tersebut digunakan menjadikan suasana belajar terasa santai, siswa dapat belajar dan siap berkonsentrasi.

Dari uraian tersebut diatas maka dapat dipertegas bahwa lingkungan kelas adalah upaya penciptaan suasana belajar atau suasana kelas belajar sehingga interaksi di dalam kelas kondusif. Di mana suasana kelas belajar berlangsung santai bermakna, demokratis, adil,religius, dan siswa dapat belajar dan siap untuk berkonsentrasi. Di samping itu ketika siswa sedang bekerja/ mengerjakan suatu masalah dalam dapat diputarkan musik belajar. ${ }^{11}$

Oleh karena itu peran guru harus membiasakan peraturan peran serta/ tanggung jawab setiap siswa terhadap terciptanya lingkungan fisik kelas yang diharapkan dan suasana lingkungan sosial kelas yang menjadikan proses pembelajaran pada tiap siswa menjadi lebih bermakna. Dengan terciptanya tanggung jawab bersama antara siswa dan guru maka kebersamaan akan terbentuk sehingga hal (lingkungan belajar) untuk menjadikan pembelajaran berenergi menjadi tuntunan tiap siswa. Hal yang menjadikan pembelajaran berenergi adalah tanggung jawab bersama tiap siswa.

B. Cara untuk menciptakan lingkungan belajar yang efektif

Dalam rangka memaksa memaksimalkan proses pembelajaran anak, memerlukan lingkungan positif. Untuk menciptakan lingkungan yang positif diperlukan strategi manajemen kelas, dan strategi positif untuk membuat anak mau bekerja sama. Menurut Santrock, strategi umum manajemen kelas untuk menciptakan lingkungan positif bagi anak mencakup pembangunan gaya otoritatif dan manajemen kelas secara efektif. ${ }^{12}$

Gaya manajemen kelas otoritatif berasal dari gaya parenting, dimana guru yang otoritatif akan mempunyai siswa yang cenderung mandiri, tidak cepat puas, mau bekerja sama dengan teman, dan menunjukkan penghargaan diri yang tinggi. Manajemen kelas otoritatif, mendorong siswa untuk menjadi pemikir yang independen dan pelaku yang independen, tetapi strategi ini masih menggunakan sedikit monitoring siswa.

Guru otoritatif akan menjelaskan aturan, regulasi dan menggunakan standar dengan masukan dari siswa gaya otoritatif bertentangan dengan gaya otoritarian dan permisif yang tidak efektif.

Gaya manajemen kelas otoritarian fokus utamanya adalah menjaga ketertiban di kelas, bukan pada pengajaran dan pembelajaran. Guru otoriter sangat mengekang dan mengontrol perilaku siswa, sehingga siswa di kelas cenderung pasif tidak berinisiatif dalam aktifitas, memiliki keterampilan komunikasi yang

11 Mulyasa, Kurikulum Yang Disempurnakan. Perkembangan Standar Kompotensi dan Kompotensi Dasar. (Bandung : Remaja Rosdakarya, 2006), h 210

12 Reostiyah dan Yumiati Suharto, Strategi Belajar Mengajar. (Bandung:Bina Aksara,1995), h. 82 


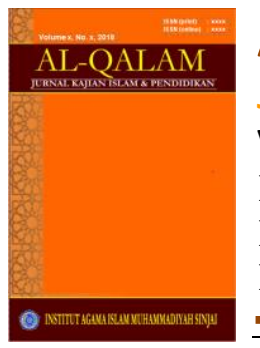

AL-QALAM

Jurnal Kajian Islam \& Pendidikan

Volume 06 No 022014

ISSN (print) : :1858-4152

ISSN (online) : -

Homepage : http://journal.iaimsinjai.ac.id/index.php/al-qalam

buruk. Sedangkan gaya manajemen kelas yang permisif, member banyak otomi pada siswa tapi tidak member banyak dukungan untuk pengembangan keahlian pembelajaran atau pengelolaan perilaku. Siswa di kelas permisif, cenderung punya keahlian akademik yang tidak memadai dan kontrol diri yang rendah.

Manajemen kelas secara efektif adalah upaya yang dilakukan guru dalam mengelola aktifitas kelas secara efektif. Menurut Santrock, ${ }^{13}$ guru efektif berbeda dengan guru yang tidak efektif bukan dengan cara merespon perilaku menyimpan siswa, guru yang berperan sebagai manajer kelas yang efektif senantiasa mengikuti apa yang terjadi, selalu memonitor siswa secara regular, sehingga dapat mendeteksi perilaku yang salah jauh sebelum perilaku itu lepas kendali. Guru efektif mampu mengatasi situasi yang over-lapping secara efektif, menjaga kelancaran dan kontuinitas pelajaran, serta melibatkan siswa dalam berbagai aktifitas yang menantang.

Agar proses pembelajaran dapat berjalan lancar, maka kelas perlu punya aturan dan prosedur yang jelas. Tanpa aturan dan prosedur yang jelas, biasa memunculkan kesalah pahaman yang bisa melahirkan kekacauaan. Aturan dan prosedur adalah pernyataan ekspektasi tentang perilaku. Aturan fokus pada ekspektasi umum atu spesifik atau standar perilaku, cenderung tidak berubah karena mengatur dasar-dasar tindakan terhadap orang lain, diri sendiri atau tugas, seperti menghargai orang lain, tidak mengunyah permen karet dikelas. Sedangkan prosedur berisi tentang Ekspektasi tentang perilaku namun biasanya diterapkan untuk aktifitas Spesifik dan diarahkan untuk mencapai suatu tujuaan, bukan untuk melarang suatu perilaku. Prosedur dimungkinkan untuk biasa berubah karena rutinitas atau akivitas kelas biasa berubah, misalnya prosedur suatu kelas mengatakan bahwa setelah masuk kelas siswa harus mengajarkan suatu soal, akan tetapi suatu hari guru biasa mengubahnya dengan membolehkan siswa menyelesaikan tugas yang belum selesai. ${ }^{14}$

Pembuatan aturan dan prosedur dapat dirumuskan oleh guru dan dijelaskan ke siswa, namun guru dapat pula melibatkan siswa dalam merumuskan aturan dan prosedur kelas untuk menamakan rasa tanggung jawab terhadap aturan dan prosedur.

Proses ini dapat menjadi saran untuk menjalin hubungan yang positif dengan siswa dan melatih mereka untuk berbagi dan mengembang tanggung jawab.

Upaya menciptakan lingkungan positif bagi siswa dapat pula dilakukan dengan memberikan hadiah terhadap pelaku yang tepat. Untuk memberikan imbalan dalam mengelola kelas, guru harus dapat memilih penguat yang efektif, menggunakan Prompt dan Shapping secara efektif. Menggunakan imbalan yang mengandung informasi tentang kemampuan siswa yang biasa meningkatkan

\footnotetext{
${ }^{13}$ Ibid

14 E. Mulyasa Menjadi Guru Profesional Menciptakan Pembelajaran Kreatif dan Menyenangkan. (Bandung :Remaja Rosdakarya, 2005), h.53
} 


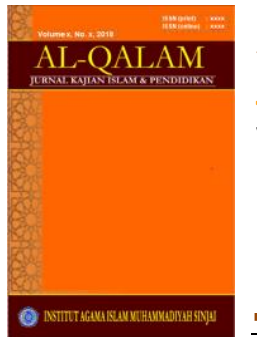

motifasi intrinsik dan rasa tanggung jawab siswa, bukan untuk mengontrol prilaku.

Menurut Naim ada dua aspek penting yang perlu dikembangkan oleh seorang guru sehingga mampu menciptakan pembelajaran yang kondusif bagi siswa, yaitu pribadi guru dan suasana pembelajaran. Perpaduan aspek tersebut akan menjadikan dimensi inspiratif semakin menemukan momentum untuk mengkristal dan membangun energi perubahan positif dalam diri siswa. Kepribadian guru sebagai orang dewasa dapat menjadi model sekaligus pengarah dan fasilitator belajar yang tercermin dari suasana atau iklim pembelajaran yang diciptakan di dalam kelas. Kedua aspek ini, pada gilirannya akan mempu mengakumulasi potensi diri para siswa untuk semakin meningkatkan kapasitas dan kapabilitasnya. ${ }^{15}$

Dalam penilitian Walberg dan grenberg (1997) dalam Doporter Bbobbi Rteadon Mark, Singer sarah-Nuurie, ${ }^{16}$ menunjukkan bahwa lingkungan sosial atau suasana kelas adalah penentu psikologis utama yang mempengaruhi belajar akademis. Dimana suasana keadaan ruangan menunjukkan area belajar dipengaruhi emosi. Sedangkan Indra Djati Sidi ${ }^{17}$ menegaskan bahwa "lingkungan yang efektif untuk belajar adalah lingkungan belajar yang dapat lebih menunjang perkembangan keterampilan, pengetahuan dan sikap yang diperlukan dalam kehidupan sehari-hari. Dalam pengelolaan tempat belajar yang efektif sangat tergantung terhadap strategi yang digunakan dan tujuan pembelajaran yang akan dicapai, juga memperhatikan intensitas interaksi antara siswa.

Yang dikelola dalam lingkungan belajar efektif adalah pajangan, meja kursi, perabot sekolah/kelas dan sumber berjalan. "suasana kelas yang kondusif sangat baik untuk perkembangan berfikir siswa. Siswa senang tinggal disana selama kegiatan berlangsung, dan sepaerti yang ditegaskan adalah Megawati Er,Melliy Latifa dan Dina W.F"18 para siswa akan bekerja lebih keras, mengerti lebih banyak serta terlibat lebih aktif di kelas ketika mereka belajar."

Adapun lingkungan belajar/kelas yang mendukung kreatifitas adalah sebagai berikut: 1)memperkenalkan persamaan yang saling menghargai, 2) membuka kesempatan bagi anak untuk kontribusi ide-ide orisinil, 3) menanggap perbedaan pendapat sebagai sumber belajar, 4) mencari cara pendekatan dengan cara memecahkan masalah, 5) mendorong anak untuk memenfaatkan fantasi dan imajinasi, 6) mengembangkan kecakapan inkuiri, kecakapan bertannya, dan mencari jawaban sesuatu, dan 7) menciptakan masyarakat belajar yang mengembangkan rasa percaya dan mengurangi resiko.

\footnotetext{
${ }^{15}$ Mulyasa,Op.Cit, h.37

${ }^{16}$ DePorter Bobbi, Rearden Mark \& Singer Sarah-Nuurie, Quamtem Teaching ( Memperhatikan Quantum Learning Di Ruang-ruang Kelas ). Terjemahannya Ary Nilandri. (Bandung : Kaifa, 2001 \}, h. 31-39

17 Paul Suparno, Filsafat Konstruktivisme Dalam Pendidikan. \{Yogyakarta :Penerbit Kanisium,2005),h. 67

${ }^{18}$ I Made Alit Maryana HO. Science For All.(Bandung,PPPG IPA. 2005),h .16
} 


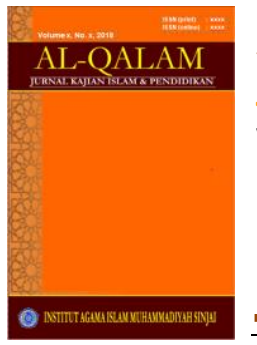

AL-QALAM

Jurnal Kajian Islam \& Pendidikan

Volume 06 No 022014

ISSN (print) : :1858-4152

ISSN (online) : -

Homepage : http://journal.iaimsinjai.ac.id/index.php/al-qalam

Dari uraian diatas tentang karakteristik lingkungan pembelajaran yang efektif adalah semua apa yang diciptakan dalam kelas pembelajaran/ruang kelas "berebicara" artinya mempunyai perang masing-masing sehingga suasana pembelajaran menggairahkan dan mencapai tujuan pembelajaran. Lingkungan belajar menjadikan siswa dalam belajar terasa gembira, tidak ada tekanan, tidak ada usaha yang tidak dihargai, tercipta masyarakat belajar (learning Communiy), dan maju bersama tiap siswa untuk mewujudkan belajar yang berenergi.

\section{Hubungan Antar Lingkungan Belajar dengan Hasil Pembelajaran}

Dalam kaitan ini Gane dalam Canggelosi ${ }^{19}$ menegaskan bahwa kondisi belajar pada dasarnya penggambaran system lingkungan belajar yang terbentuk sesuai dengan tujuannya. Kondisi belajar yang hendak dicapai tidak lain adalah bentuk akhir kompetenai siswa yang dapat dilihat pda aspek kognitif, psikomotor, dan afektif. Sedangkan menurut Dimyati" "lingkungan belajar yang sangat berperang dalam menciptakan suasana belajar menyenangkan". Lingkungan tersebut dapat meningkatkan keaktifitasan belajar. Oleh karena itu lingkungan belajar perlu ditata semestinya.

Dalam usaha menciptakan lingkungan belajar dalam konteks tujuan, Mualiyasa $^{21}$ "menegaskan terdapatnya interaksi yang saling mendukung antara variabel guru, tugas, menyangkut stukturnya (organisasi), dimensinya, cakupannya, dan nilai kebermanfaatannya. Variabel siswa, antara lain meliputi kompetensinya, motivasinya, gaya belajarnya, dan perbedaan individualnya. Sedangkan variable strategi pengelolaan pembelajaran, mencakup saran kelas, strategi, metode, dan media pembelajaran serta waktu yang dialokasikan untuk kegiatan itu."

Dengan demikian, dapat dikatakan bahwa lingkungan pembelajaran dikelas yang diciptakan baik fisik maupun sosial dan proses dialogis antara lingkungan fisik dan lingkungan sosial berpengaruh terhadap iklim pembelajaran di kelas dan tujuan pembelajaran yang dicapai. Sehingga aktifitas dalam belajar dapat berkembang dan terlayani seperti tuntutan dalam alam siswa.

D. Menata lingkungan belajar di kelas

Deperter Bobbi, Rear Dong Mark, dan Singger Sarah-Nourie ${ }^{22}$ memberikan penjelasan dalam menata lingkungan belajar(kelas) sebagai panggung belajar yang membuat lingkungan belajar/kelas yang mendukung kreatifitas, mempunyai tempat aspek, yaitu:

\footnotetext{
${ }^{19}$ Cangolosi, J.S.. Classroom Management Strategles, Gaining and Maintaining Student Cooperation. \{Scound Edition, by Logman Publishing Group,1993\}, h. 83-84

${ }^{20}$ Dimiyati, M.,\& Mudijkiono, Belajar dan Pembelajaran. Depdikbud. (Jakarta: PT . Rineka Cipta, 1999), h. 95

${ }^{21}$ Mulyasa...Op.Cit,h.60

${ }^{22}$ DePorter Bobbi, Rearden Mark \& Singer Sarah-Nuurie,Op.Cit, h.14-15
} 


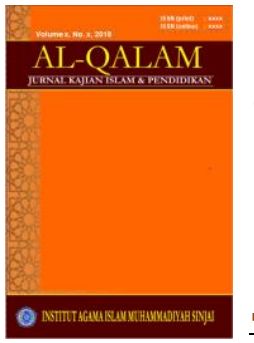

AL-QALAM

Jurnal Kajian Islam \& Pendidikan

Volume 06 No 022014

ISSN (print) : :1858-4152

ISSN (online) : -

Homepage : http://journal.iaimsinjai.ac.id/index.php/al-qalam

(1) Suasana kelas mencankup bahasa yang dipilih guru, cara menjalin rasa simpati dengan siswa, dan tiap guru terhadap sekolah serta belajar. dan suasana yang penuh kegembiraan membawa kegembiraan pula dalam belajar.

(2) Landasan adalah kerangka kerja yang berupa tujuan, keyakinan, kesepakatan, kebijakan prosedur, dan aturan bersama yang member guru dan siswa sebuah pedoman untuk bekerja dalam komunitas belajar.

(3) Lingkungan adalah cara guru dalam menata ruang kelas seperti pencahayaannya , warna, pengaturan meja dan kursi, tanaman, musik, dan semua yang mendukung proses belajar.

(4) Rancangan adalah penciptaan terarah unsur-unsur penting yang biasa menumbuhkan minat siswa, mendalami makna, dan memperbaiki proses tukar menukar informasi.

Dari penjelasan aspek-aspek penataan lingkungan belajar terlihat dalam perwujudannya dilakukan secara bersama antara siswa dengan guru sesuai dengan kebutuhan dan selera bersama. Dalam penataan lingkungan belajar yang menyangkut empat aspek yaitu suasana kelas, landasan, lingkungan, dan rancangan dibangun bersama-sama yang menjadikan siswa merasa lebih dan sebagai bagian dan merasa komunitas pembelajarannya di kelasnya atau sistem pendidikan di sekolahnya.dengan demikian bangunan lingkungan belajar di kelas memiliki dinamisasi yang diperlukan siswa dalam mewujudkan pembelajaran yang efektif.

Sejalan dengan aspek-aspek yang perlu diperhatikan dalam menata lingkungan belajar maka akan membangun suasana pembelajaran yang menarik sehingga pembelajaran akan menjadi efektif adalah perlu diperhatikan adanya: ${ }^{23}$

1) Kekuatan yang terpendam dan niat yang kuat

2) Jalinan rasa simpati yang saling pengertian, untuk menarik keterlibatan siswa, guru harus membangun hubungan, sebagai jembatan yang menuju kehidupan bergairah siswa, mengetahui minat kuat siswa, berbagi kesuksesan puncak siswa, dan berbicara dengan bahasa hati siswa

3) Keriyangan dan ketakjuban; jika guru secara sadar menciptakan kesempatan untuk membawa kegembiraan ke dalam pekerjaan guru, kegiatan pembelajaran akan lebih menyenangkan. Kegembiraan membuat siswa siap belajar dengan lebih mudah dan bahkan dapat mengubah sikap negative. Disamping itu untuk lebih banyak kegembiraan dalam pengajara maka guru perlu dipertimbangkan dalam hal afirmasi(penguatan atau penugasan), pengakuan dan perayaan terhadap setiap keberhasilan siswa sekecil apapun.

23 Suryabrata,S,Proses Belajar Mengajar di Sekolah. (Jakarta:PT. Rineka Cipta, 2002),h,72 


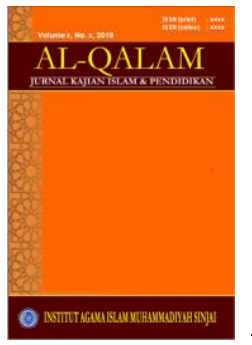

4) Pengambilan resiko; belajar itu mengandung resiko. Setiap kali kita bertualang untuk belajar sesuatu yang baru, kita mengambil resiko besar diluar zona nyaman kita. Zona nyaman merupakan daerah kehidupan yang membuat rasa nyaman atau daerah yang melekat pada rutinitas yng menonton. Maka guru perlu mengupayakan dengan resiko apapun dan pertimbangan yang maka harus dapat keluar dari zona tersebut dari kebiasaan hal-hal baru.

5) Rasa saling memiliki ; membangun rasa saling memiliki akan mempercepat proses pengajaran dan meningkatkan rasa tanggung jawab. Hal ini maka perlu menciptakan tradisi menumbuhkan rasa saling memiliki. Tradisi yang paling bagus adalah tradisi yang diciptakan bersama oleh guru dan siswa. Sebab ini akan menbuahkan tradisi kebanggaan kebersamaan, dan kegembiraam dalam belajar.

6) Keteladanan; keteladanan membangun hubungan, memperbaiki kredibilitas, dan meningkatkan pengaruh. Akan lebih baik melakukan tindakan atau member contoh (modeling) dari pada berbicara saja.

\section{KESIMPULAN}

Berdasarkan pembahasaan yang telah penulis kemukakan di atas, maka kesimpulan yang bisa penulis ambil adalah sebagai berikut:

1. Lingkungan belajar merupakan situasi buatan yang menyangkut lingkungan fisik dan lingkungkungan sosial.

2. Untuk menciptakan lingkungan belajar yang efektif diperlukan strategi manajemen kelas, dan strategi fositif untuk membuat anak mau bekerja sama.

3. Kondisi belajar pada dasarnya penggambaran sistem lingkungan belajar yang terbentuk sesuai dengan tujuannya, karena lingkungan belajar sangat berperan dalam menciptakan suasana belajar menyenangkan.

4. Ada empat faktor penting jika ingin menciptakan lingkungan belajar yang efektif di dalam kelas, yakni suasana kelas, landasan, lingkungan dan rancangan. 


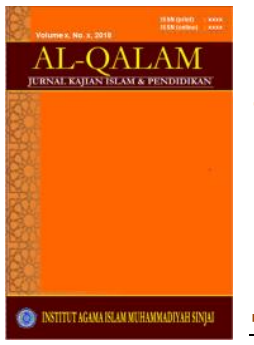

\section{DAFTAR PUSTAKA}

Cangelosi, J.S.. Classroom Manugement Strategies,Gaining and maintaining student Cooperation. Second Edition, By logman Publishing Group, 1993.

Deporter Bobbi, Reardon Mark \& Singger Sarah-Nuurie, Quantum Teaching (memperhatikan Quantum Learning diruang-ruang kelas). terjemahan Ary NIlandri. Bandung: Kaifa,2001

Dimiati , M.,\& Mujiono, Belajar dan Pembelajaran. Depdikbud, Jakarta: PT. Rineka Cipta , 1999.

I Made Alip Mariana Ho. Science For All. Bandung, PPPG IPA, 2005

Kusmoro, Pengaruh Model PAKEM Dengan Pendekatan Konstruktivisme dan Cooperative Learnig Dalam Pembelajaran Sains Di Tinjau Dari Lingkungan Belajar Siswa .Tesis UNS:Tidak Ditertibkan :2008.

Mariana, I Made Alip HO Science For All, PPPG IPA :Bandung, 2005.

Mulyasa, Kurikulum Yang Disempurnakan Perkembangan Standar Kompetensi dan Kompetensi Dasar .Bandung :Remaja Rosdakarya, 2006.

Mulyasa, Menjadi Guru Profesional Menciptakan Pembelajaran Kreatif dan Menyenangkan. Bandung :Remaja Rosdakarya,2005.

Paul Suparno ,Filsafat Konstruktivisme Dalam Pendidikan. Yogyakarta :Penerbit Kanisium, 2005.

Rianto, Milan Pengelolaan Kelas Model Pakem.Jakarta:Dirjen PMPTK, 2007

Roestiyah dan Suharto,Yumiati.Strategis Belajar Mengajar (Bandung:Bina Aksara 1995)

Semiawan, Conny dkk, Pendidikan Keterampilan Proses, Bagaimana Mengaktifkan Siswa Dalam Belajar. Jakarta :PT Graamedia, 1992.

Suparno, Paul Filsafat Konstruktivisme Dalam Pendidikan, Yogyakarta :Penerbit Kanisium, 2005.

Suryabrata ,S, Proses Belajar Mengajar di Sekolah. Jakarta :PT.Rineka Cipta, 2002. 